\title{
Erratum
}

\section{MicroRNA-26a and -26b inhibit lens fibrosis and cataract by negatively regulating Jagged-1/Notch signaling pathway}

Xiaoyun Chen, Wei Xiao, Weirong Chen, Xialin Liu, Mingxing Wu, Qu Bo, Yan Luo, Shaobi Ye, Yihai Cao and Yizhi Liu

Cell Death and Differentiation advance online publication, 22 September 2017; doi:10.1038/cdd.2017.147

Correction to: Cell Death and Differentiation (2017) 24, 1431-1442; doi:10.1038/cdd.2016.152; published online 16 June 2017

This article was originally published under a standard license, but has now been made available under a CC BY 4.0 license. The PDF and HTML versions of the paper have been modified accordingly.

\begin{abstract}
(c) (1) This work is licensed under a Creative Commons Attribution 4.0 International License. The images or other third party material in this article are included in the article's Creative Commons license, unless indicated otherwise in the credit line; if the material is not included under the Creative Commons license, users will need to obtain permission from the license holder to reproduce the material. To view a copy of this license, visit http:/l creativecommons.org/licenses/by/4.0/
\end{abstract}

(C) The Author(s) 2017 